DODONOV ROMAN,

Doctor of Philosophy, Professor,

Borys Grinchenko Kyiv University

\title{
PECULIARITIES OF SHIPPING IN THE DNIPRO BASIN IN 1875-1932
}

The article is devoted to analysis of the dynamics of water transport in the Dnipro basin in the last quarter of $19^{\text {th }}$ - the first third of the $20^{\text {th }}$ century. Under the influence of technological innovations during this period, the structure of the fleet of ships is changing radically, the total tonnage increases, the speed of transportation, the cost of services decreases. The Dnipro begins to work for the needs of the industry, which is booming on its shores. It proves the need of river traffic, its direction, due to the meridional orientation of the river, describes the evolution of the river fleet, steamships too. The article reveals the conditions of navigation and the specifics of navigation on the Dnipro (before the construction of the dam of the Dnipro hydroelectric station).

Key words: Dnipro; Dnipro basin; river transport; steam ships; rapids; Dniprostroi.

The problem statement. Peculiarities of shipping in the Dnipro basin in the last quarter of the $19^{\text {th }}$ century - the first third of the $20^{\text {th }}$ century is the subject of our discourse. This period evidenced the combination of traditional methods of transportation by water with advanced innovations of the epoch and thus it is a matter of interest. Technological innovations such as steam engine, metal body, propeller screw and soon - combustion engine caused a true revolution in river transport. Since the end of 1870 s, as we'll see it later, the structure of the river fleet had drastically changed, their total tonnage increased and their prime cost had sufficiently reduced, while the speed of transportation had increased. One may say, that during that period, the Dnipro was actively used to satisfy the demands of the industry which was vigorously developing on its banks. At the same time, the geographic conditions which determine the space cut-off of the chronotope remain unchanged till the very end of the period under analysis. The developed river system of the Dnipro, considering not just the major bed but partially, its navigable feeders (the Prypiat, the Sozhzh, the Desna) embraced a large European territory (half a million square kilometers) populated with $22 \mathrm{mln}$ people. The length of river fairways was over two thousand kilometers.

An overall meridian positioning of the Dnipro river system seemed to provide numerous advantages, uniting different nature and climatic regions (the steppe, the foreststeppe and the forest region), but geologic conditions "failed" here. Since the times of the great glacier melting, which searched the shortest way to the South through the granites of the Ukrainian crystalline shield, the rapids remained in the Dnipro bed to bring to naught all prospective advantages provided by the geography to the development of these lands. A large river bed area with multiple rapids between Katerynoslav (now the city of Dnipro) and Oleksandrivsk (now the city of Zaporizhzhia) was excluded from navigation which actually divided the river into two almost separate areas. The headwaters from Mogileov to Kremenchuk (1 810.22 miles) were isolated from the lower reaches (Oleksandrivsk-Kherson). Due to this, the Steppe experienced a severe shortage in timber, while the Naddniprianska Ukraine was unable to establish a cheap and safe way for bread export. Such isolation and impossibility of easy ship traffic along the whole river bed was conventionally called the issue of the "Great Dnipro" which sufficiently differentiated the basin of the latter from the basins of the Volga, Danube, Don as well as rivers of Siberia and the Far East.

Thus, the essence of the problem may be rendered as an intensive collection of civilization achievements in navigation which closely lead to the solution of the "Great Dnipro" issue through flooding the area of the rapids due to the construction of Dniprelstan dam.

Analysis of recent studies and publications. This problem was reflected in the publications of $A$. AfanasyevChuzhbinsky [1861], P. Balitsky, P. Belyavsky [1991], G. Graftio [1905], I. Gurzhiy [1968], V. Dudka and L. Dudka [2010], S. Zhitkova, K. Zavalniuk [1998], A. llovaysky, V. Konstantinova [2010], I. Krivko [2006], O. Morozova, O. Sandurskaya, I. Sokolova, I. Chernikov [2003] and others.

The goal of this article is to reveal the peculiarities of navigation in the Dnipro basin in 1875-1932.

Demand in River Traffic and its Directions. Shipping, like any other transportation method, vigorously develops when you have a cargo to be carried to a definite destination. This fundamental truth may be highlighted by the dynamics of quantity and tonnage of ships on the Dnipro in the last quarter of the $19^{\text {th }}$ century. Social processes occurred in the Russian Empire after the reforms of the 1860s, mainly, the liberation of peasants, facilitated the formation of the nationwide market which caused the increase of money and commodities turnover. Timber, strongly demanded in the South, was the basic resource of Belarus guberniyas. Annually, the wharfs of Mogyleov and Minsk guberniyas shipped several million poods (a pood is a measure of weight; 1 pood is equal to $16 \mathrm{~kg}$ ) of timber for civil works. One should mention, that river transport workers were also a major consumer of timber: since the steam ships used wood as their fuel instead of coal and petroleum products, wood was highly demanded. Wood for steam ships had 
to be stocked at every wharf. Therefore, wood made a major portion of all river cargoes. In 1889, 102 mln poods of timber and wood were transported by river. In 1893, 3034116 poods of timber were shipped from Shklov wharf of Mogyleov guberniya, 5886078 poods - from Orsha, 2660675 poods - from Bykhov, 4549540 poods from Rogacheov. Even in 1913, timber made up to $55 \%$ in total quantity of cargoes shipped [Завальнюк, 1998].

Resin, charcoal, oakum, tar, lime, turpentine and alcohol were exported from Belarus apart from timber. Steady trade relations were established between the lands of Dnipro headwaters and Kremenchuk. A resin-producing plant was working especially for the latter in Vysoke estate of Mozyrsky povit (a territorial unit), as well as three resin and turpentine-producing plants in the town of Smolevychi (Borysivsky povit) and a resin-producing plant in Chervytsi estate of Pinsky povit (Minska guberniya). Resin was usually transported by specially-equipped rafts.

The Middle Naddniprianshschyna exported mainly agricultural products. Kyiv, Cherkasy, Kremenchuk shipped flour, vegetables, mainly, potato, sugar, pork fat for stearine factories as well as metal products. In $1889,1.2 \mathrm{mln}$ poods of sugar were transported by the Dnipro [Афранасьев-Чужбинский, 1861: 228].

In the course of time, the Lower Naddniprianshschyna became a powerful bread-maker. Grain to be exported to Europe was carried from Oleksandrivsk, Kherson and Oleshky to Odessa. Sault from the Crimea and hard coal from Donbas were also brought here. In the same 1889, $42 \mathrm{mln}$ poods of bread, $3.6 \mathrm{mln}$ poods of salt and 1.6 poods of coal were transported [Афранасьев-Чужбинский, 1861: 228]. In 1913, grain made $27 \%$ of total annual cargo turnover.

And this flow tended to increase. An average cost of cargoes transported by river increased from $162 \mathrm{mln}$ rubles in 1888-1892 to $270 \mathrm{mln}$ rubles in 1908-1912. According to the statistics of 1912, 2260 thousand tons of cargoes and $2.4 \mathrm{mln}$ passengers were transported by the Dnipro.

Shipping Conditions. Navigation in the Dnipro basin was determined by several natural and climatic aspects, in particular, water level and relatively, depth of the fairway and near-bank area waters, weather conditions, type of bottom and bank line.

Water level of the Dnipro directly depended on the season, thus peak transportations were carried out during floods. In hot summer days, the river became shallow thus making shipping impossible. The period of boundary water level decrease lasted 60-70 days approximately [Обозрение экономической статистики..., 1849: 252]. Climatic fluctuations determined the extreme points of navigation beginning and completion. In the headwaters, navigation started in the beginning of April and continued till November with an interruption from June to August. In the area between Kyiv and Kremenchuk, navigation lasted from the beginning of March till the beginning of December without any interruptions. In the midsummer, the water level drop affected just the tonnage of the ships. From Kremenchuk to Katerynoslav, some smaller ships (draft below $1 \mathrm{~m}$ ) were traveling which allowed them to easily pass the rocky areas. In the lower reaches, navigation started in April. Such delay was caused by the necessity to hold off the spring flood, which positively influenced the rate of ship traffic in the middle stream but was highly dangerous in the area of Dnipro rapids. This was also the reason of early navigation completion (in October) in the lower reaches.

Peculiarities of the river bed, bottom composition and features of the bank line also affected navigation. In many places, the Dnipro bottom was covered with stones and snags. Sandy bottom and a relatively fast as for a plain river, stream lead to the frequent changes of the fairway in some areas, caused the appearance of shoal areas in different places and the search of new locations for cargoes handling. For example in Cherkasy, where people failed to establish a port area within the city due to the features of the bank line, the wholesale trade was carried out in the near-by villages. This facilitated the development of harbors, approach roads and the villages. Vasyltsi village served as a wharf for Cherkasy. It was located 3 versts (1.9887 miles) from the administrative (povit center), from where the overland ways lead to Yelysavetgrad, Novomyrgorod, Uman, Smila and other towns of the Pravoberezhzhia (territories on the right bank of the Dnipro) [Дудка, Дудка, 2010: 50].

The peculiarities of the river system also determined the direction of traffic flows that ran by the Dnipro. In the area from Smolensk to Mogyleov, little depth and narrow bed sufficiently restricted floating down the stream. In other sections, including the rapids, it was possible to move downwards till the very mouth considering the season. On the contrary, traffic against the stream was only possible from Kremenchuk to Shklov. Despite the fact that the steam ships were operating in the mouthes of the Prypiat and the Desna, navigation to Mogileov was mainly viewed as an exception and was allowed only during short periods of high water level. In 1880s, there were up to three dozens of large shoal areas which size and location changed annually.

Weather also affected navigation: strong waves, cross and side wind. Changes in weather frightened the steam ships owners who strictly prohibited captains to sail in stormy and the like weather.

The Fleet. The peculiarities of navigation specified above determined the requirements for the fleet of ships used at the Dnipro: a small draft (approximately 5-5.5 quarters of arsheen, i.e. up to 1.3 meters), high maneuvering ability, an ability to move against the stream, etc.

A large quantity of wooden sailing and oared boats passed from the previous years to the epoch under analysis. But in the course of time they became less significant and owners started preferring steam ships. Though the quantity of ships without a steam engine exceeded the quantity of steam boats, the tonnage of the latter was higher. In 1880 s, steam ships prevailed over the ships without a steam engine as the method of cargo transportation. At the end of the decade, $96.5 \%$ of the total bread amount shipped from the wharf of the Lower Dnipro to Odessa were carried by barges towed by steam tug boats [Гуржій, 1968: 187]. The same ratio was preserved at other distances.

As per data of 1890, the fleet of non-self-propelled ships of the Dnipro basin upstream of the rapids included 934 ships with a primary cost of 371.5 thousand rubles (an average cost of one ship was 1.5 thou. rubles), a total tonnage of $13.8 \mathrm{mln}$ poods and a total crew of 6,442 people. Respectively, downstream of the Dnipro rapids, there were 880 ships with a primary cost of $5.5 \mathrm{mln}$ rubles (an average cost of one ship was over 6 thou rubles), a total tonnage of $10.8 \mathrm{mln}$ poods and a total crew of 3,386 people [Обозрение экономической статистики..., 1849: 54]. Before the First World War, there were 382 steam ships and 2,218 ships without a steam engine in the Dnipro basin.

Steam Ships. It is known that the first steam ship appeared on the Dnipro in 1823 and was named "Nadiya" 
(hope). Till 1875, the number of steam ships was continuously increasing. This was facilitated by the activity of Russian Community for Steam Shipping and Trade (ROPYT) and Community for Steam Shipping on the Dnipro created in the middle part of the century. Private ship owners also played a significant role in this process. Thus, at the end of the 60s, ROPYT owned 15 steam ships with a total power of over 1 thou. hp. Community for Steam Shipping on the Dnipro owned 9 steam ships with a total power of $520 \mathrm{hp}$. Merchants Levin and Rabinovych owned 5 ships, Yakhnenko and Symyrenko 2 ships. Private owners possessed 40 steam ships with a total power of over 1.9 thou hp.

The steam ships were built in Briansk, on Desna and Bolva, in Kyiv at "Robitnyk" plant, in Hrodyshche at Cherkasy region at Yakhnenko's plant, in Kherson at Vadon brothers' plants. Some of the ships used on the Dnipro were built abroad. Community for Steam Shipping on the Dnipro owned such passenger steam boats as "Oleksandr II" (60 hp, built in 1858), "Volodymyr" (50 hp, 1858), "Dnipro" (50 hp, 1839, rebuilt in 1858), "Katerynoslav" (60 hp, 1859), "Ivan Bilousov" (60 hp, 1858), "Kyiv" (60 hp, 1859), towing steamers "Kremenchuk" (60 hp, 1859), "Poltava" (60 hp, 1848), etc.

In 1888, The Second Community for Steam Shipping on the Dnipro and its Feeders was established. This stock company included sugar-mill owners of Kyiv and Podillia regions, owners of Donetsk mines and shareholders of Bryansk plant in Katerynoslav. The goal of the new Community was to invest into the insufficiently developed field of steam shipping on the Dnipro upstream of the rapids - cargo-carrying ships (transportation of metal, coal, sugar) which in the course of heavy industry development in Prydniprovya and Donbas regions provided the shareholders with high dividends. The new steamship line owned ten wharfs on the Dnipro. Since 1888, it started regular passenger trips between Kyiv and Kremenchuk as well as between Katerynoslav and Kremenchuk. In 1889, the The Second Community for Steam Shipping on the Dnipro owned 15 steam ships, included the largest ones on the Dnipro ("Tsar-paroplav" and "Derzhava"). The next year, the Company purchased six more steam ships. In course of time, the capital stock of the company reached $1 \mathrm{mln}$ rubles [Кривко, 2006: 76].

Severe competition between the two Communities finally lead to their consolidation. But even after this it was impossible to establish a monopoly, since private owners continuously reduced prices on passenger shipping.

In total, as per inventory of 1890 , there were 220 steam boats with a tonnage of $1.2 \mathrm{mln}$ poods, a total engine power of 11.2 thou. hp and the total crew of 2 thou. persons. This made $10-13 \%$ of the total empire values. Upstream of the Dnipro rapids, there were 131 steam ships in operation. Their total cost was 3876559 rubles, tonnage - 360225 poods (including 74 passenger, 2 cargopassenger, 39 towing-passenger, 7 towing and 9 service steam ships). Downstream of the Dnipro rapids, there were 103 steam ships with a total cost of 7174125 rubles and tonnage of 917950 poods (including 16 passenger, 9 cargo-passenger, 11 cargo-carrying, 14 towing-passenger, 38 towing and 15 service steam ships). While passenger steam ships prevailed upstream of the rapids, towing ships prevailed downstream of the rapids.

The number of steamboat crewmen on a line depended on their designation, but an average number ranged from 10 to 20 persons. Monthly salary of a steam boat sailor upstream of the Dnipro rapids in navigation season was 24.6 rubles., in winter period- 35.2 rubles; downstream of the rapids - 33.1 and 40.6 rubles [Кривко, 2006: 78].

Ships without Steam Engines. Ships without steam engines embraced two dozens of titles, including barges, berlynas (tonnage: from 10 to 50 thou. poods), barques, baidaks, semi-baidaks, bilyans (large flat-bottomed boats of unpainted wood; used to transport timber), bryankas, galleys, dubs, donbases, honchaks, pidchalkas, lyzhvas, Finnish boats, liuzes and boats (up to 5 thou. poods). Sailing brigs, scows, schooners and trebaks were cruising downstream of the Dnipro rapids. The majority of them were owned by merchants, trade and stock companies.

While in the beginning of the $19^{\text {th }}$ century, barques (single- and threemasted sailing river boats with a flat bottom) were the most spread type of cargo-carrying ships on the Dnipro, in the second part of the century, berlynas or bilyans prevailed. These were river singlemast boats with a sharp prow protruding over the stern to improve maneuvering ability. Baidaks and semi-baidaks were traditionally spread. These were also single-mast boats like berlynas but larger and sometimes with a deck. Due to the draft of 7-8 quarters of arsheen (1.3-1.4 m), this flatbottomed ship when fullyloaded (from 20000 to 40000 poods) could pass through riffles and shoal areas.

It's clear that sailing and oared boats couldn't compete with cargo-carrying steam boats and were used for auxiliary purposes. In 1884, there were 1,725 non-self-propelled vessels, in $1895-1,877$, in $1900-2,205$ vessels. The quantity of ships without steam engines increased, primarily, due to the increase in quantity of barges and berlynas, intended for towing with steam ships Кривко, 2006: 95]. In 1890, downstream of the Dnipro rapids, there were 220 barges with a total tonnage of over 6 mln poods and 660 sailing boats with a total load carrying capacity of $5.4 \mathrm{mln}$ poods. The following values are very speaking: if an average cargo-carrying capacity of a steam ship was 2527 thou. poods, the cargo carrying capacity of a sailing boat was just 8,2 thou. poods.

The major centers of non-selfpropelled ships construction were the following guberniyas: Mogyleovska (the towns of Dubrovka, Shklov, Zhlobyn), Minska (the towns of Loyiv, Rechyshsca, Kamenka) and Chernigivska (the town of Lyubechi) [Обозрение экономической статистики ..., 1849: 54-55]. Traditional technologies known since the times of Kyivska Rus' were used in the ship building. Totally, there were 50 ship building sites in the Dnipro basin (14 upstream of the rapids; 6 - downstream of the rapids; 12 - on the Desna river and its feeders; 8 - on the Prypiat; 8 - on the Sozhzh, 2 - on the Berezyn) and many temporary ship yards. Just from 1879 to 1888 , all the ship yards of the Dnipro basin built 2,456 ships without a steam engine with a total cost of 3780756 rubles [Графpmuo, 1905].

An average cost of the vessels was as follows: Berlyn: from 600 to 1,400 rubles (silver); baidak: from 700 to 1,200 rubles (silver); semi-baidak- from 300 to 700 rubles (silver); barques - approximately 300 rubles (silver). Relatively high ratio of price/tonnage for barques and baidaks may be explained by the fact that the majority of them were disassembled in Kherson for constructional timber.

Non-self-propelled fleet was attended by the largest number of river transport workers on the Dnipro. In 1890, downstream of the rapids, there were 706 ships without steam engines, including 660 wooden (the total number of crewmen: 2.8 thou. sailors). Moreover, 481 ships were serviced by $2-4$ persons and 225 ships were serviced by 
5-10 persons [ДАЗО. фр. 1 , оп. 1, спр. 825, арк. 117]. In 1895 , on all Ukrainian rivers, over 11.2 thou. crewmen worked at 2.2 ships without steam engines.

An average salary of the crew at the ships without steam engines was: upstream of the rapids during navigation: 19.1 rubles; in winter - 35.2 rubles; downstream of the rapids during navigation: 5 rubles, in winter - 17.9 rubles. I. M. Kryvko states: "Ship owners found it necessary to retain a part of the salary till navigation completion as a guarantee pledge. Deductions were lawfully made from the salaries of loaders and sailors used by the ship owners for their abusive practices. One should also note that ship owners at small wharfs (where there were no loader crews) used sailors to unload the cargo holds for a lesser salary than that of loaders" [Кривко, 2006: 78-79].

Working conditions of river transport workers were rather severe. If an average speed of movement downstream of the Dnipro was $50-60 \mathrm{~km}$ per day, against the stream, it was $25-35 \mathrm{~km}$ per day. A river stream was driving the ships. If conditions were favorable, sails were used. Poles were used for maneuvers near the banks, while anchors and oars were used at the depth. When the water was high and the weather was calm, ships moved due to the so-called "iron anchor" which acted like a hoist. In summer, poles were used in shoal areas, and where banks allowed - towing was used. The labor of haulers was used.

Timber Rafting. Timber rafting downstream from the Dnipro headwaters was an important activity of river transport workers. This was implemented in two ways: using rafts and ships intendedly built for a single navigation. The rafts were constructed in the "forest" guberniyas: Smolenska, Vitebska, Minska, Mogileovska. Chunks prepared for transportation were bound together in blocks so that they could be either combined to increase the raft square or unbound to pass the narrow sections. The destinations were Kyiv, Kremenchuk, Katerynoslav, sometimes Oleksandrivsk and Kherson. "Just from the headwaters of the Guta river (Berezynska system), about 10,000 construction chunks were annually delivered to Kremenchuk..." [Завальнюк, 1998].

Each raft was accompanied by the dubs (a boat type) and driven by five persons. The raftmen were lead by otamans - mainly, Old Belivers, who lived in Radul sloboda (administrative unit) [Гуржій, 1968: 157]. In spring, they hired peasants who grew poor, especially among day laborers, in request of regional administrations. Generally, an agreement was concluded till Illya's day (July, 20). Otaman's salary was 3,060 rubles, a raftman received 1,222 rubles. Major part of the money was paid in advance in regional administration in winter, when peasants had especially rough times, the other part was paid during chunks launching. Some insufficient money they received at a destination point.

Raft handling required some definite skills and experience, since weather conditions and river behavior could break the chunk bandage. Often, the rafts took the bottom, and in summer, there were thousands of rafts and separate chunks in shallowed Dnipro.

In 1870-1880s, 40-50 thou. people were engaged in rafting. Sometimes, women also worked at rafts, but they received a lower salary than men, since it was reasonable for them to do this work only when the whole family was going downstream. In the second half of 1880-90s, rafting somewhat reduced (from 10 thou. rafts in the 70 s to 7 thou. rafts in the 90s). The number of raftmen decreased as well.
The other way of timber transporting to the South was to build a single-trip ship from it. In sawmills, fresh planks were prepared for this purpose: bark was removed and the ships had never been caulked. Timber preserved its white color and this might have given the name to this kind of ships - bilyans (the white-colored). Such ships had a large tonnage and generally, low navigable capacity. The bilyans had a flat-bottomed body sharpened in the prow and stern sections. Distance between the frames was less than half a meter which made the body very sound. They were intended for rafting downstream and disassembly into construction materials at the destination point. Sometimes, timber was the only cargo.

Obviously, this technology of timber carrying was borrowed from the natives of Volga region. For deeper rivers, such as Bila, Volga, Vetluga and Don, the bilyans of cyclopean size were constructed. In some cases, their length reached $120 \mathrm{~m}$ and board height was $6 \mathrm{~m}$. Tonnage of an average-sized bilyan was $100-150$ poods, tonnage of the largest ones was up to 800 poods. Due to the clear reasons, the Dnipro bilyans were sufficiently smaller.

In the bilyans, timber wasn't just arranged in stacks, but in stacks with multiple spans for access to the bottom in case of leakage. Contact of cargo and sides should have been strictly avoided. But since there was water pressure outside the ship, special-purpose wedges were provided between the cargo and the sides which were replaced by larger ones in the course of their shrinkage. Once the height of loaded timber exceeded the hight of ship sides, chunks were arranged so that they protruded over the boards. Such protrusions were called "oversizings" and it was necessary to arrange them so that they didn't affect the ship's balance. New chunks and planks were placed thereon. Moreover, the oversizings protruded over the sides by four meters and therefore, the ship's width in its upper part was sufficiently larger than in its lower part and sometimes reached 30 meters. The ship was attended by the crew of 15-35 persons, including pump operators who removed water from the cargo holds. Bilyan body was built from fresh non-caulked timber and had multiple leakages, thus 10-12 pumps were provided there. That's why bilyans were loaded so that their prow part went down deeper under the water than its stern part, and all the water drained to the prow.

Once bilyans reached their destination, they were disassembled completely: chunks, bars, planks, black oakum, metal fasteners, mat bast, ropes - everything was sold generating profit to its owners. While the networks of railways spread, bilyans disappeared from the Dnipro as a ship type, since some of them could be observed on some other rivers even in the 20 s of the $20^{\text {th }}$ century. Some other wooden ships were constructed to supply timber through the Dnipro: bryankas, galleys, liuzes. It wasn't unprofitable to keep them afloat for more than one season.

Arrangement of Navigations. Growth of navigation on the Dnipro required urgent regulation and establishment of water traffic rules. Heritage of the $19^{\text {th }}$ century when there was a minor quantity of steam ships and sailing and oared boats were only limited by natural conditions negatively influenced the behavior of captains under new conditions when cargo-carrying and passenger steam ships were moving in several rows. The speed of movement had also increased: if before 1875, it took 1.5-2 days for a steam ship to reach Kyiv, now it took them one day to cover this distance.

Major ship owners competed for scheduled trips, their correspondence to the schedule, on-time delivery of 
cargoes and quality of passenger handling. This was mainly achieved by saving salaries of low-qualified personnel and violation of safety rules. Misbehavior of river transport workers, rafters, in particular, who often created emergency situations on the fairways, lead to the introduction of navigation inspection.

Traffic jam of rafts, chunks, minor wooden ships, boats etc near the Dnipro shoal areas was typical for the 80 s of the $19^{\text {th }}$ century. This caused delays in steam ships arrivals. Delays of steam ships arrival for a day caused by large number of shoal areas and blockage of fairway with rafts and berlynas was a typical event. Passengers had to wait long hours till the steam ship was removed from a shoal or a passage for the ship was cleared. In the headwaters, shipping traffic was hindered by floating water mills whose owners didn't hurry to raise anchor and blocked the ship's way. To resume the trip, a captain had to dispatch sailors to "assist" millers to come ashore. This took much time and delays in steam ships arrival became unavoidable.

Such conditions lead to accidents, especially in lowwater seasons. Testimonials about a tragic accident that took place on a passenger steam ship "Ratmir" in the second half of June, 1897 had been preserved in the archives. The steam ship was going from Kremenchuk to Katerynoslav. When it "approached the railway bridge across the Dnipro, its chimney started falling and then it broke producing much noise and fell on the deck breaching it and squeezing one commoner to death. Panic started among the passengers, many of them thought that an accident typical for the summer time on the Dnipro occurred and thus they started jumping in the water. "Ratmir" had to stop and only in half an hour captain and his mate could calm down the passengers. Many of them returned to Kremenchuk by boats since they didn't want to continue their trip. This was explained by the fact that accidents had previously occurred at "Ratmir". On June 20, 1897, "Ratmir" got in another accident by running on the underwater rock which cover the Dnipro bottom near Katerynoslav [Черников, 2003: 231-232].

Therefore, interference of government in river transport regulation was on time. The rearrangement started in 1865, when previously separate Mogyleov, Kyiv and Katerynoslav shipping traffic offices were subordinated under the single district office in Kyiv. This office had many functions.

For example, in 1878 it started cleaning Dnipro and Prypiat beds from snags and stones. There was lack in equipment for fairway cleaning, thus cleaning work proceeded very slowly. In 1898, construction of Kyiv repair workshops started in Obolon district to repair steam ships, dredgers and various river equipment.

To improve shipping conditions after recession of spring flood, temporary shields were installed on riffles to deflect the stream and direct it into the main fairway. Warning signs with an option of highlighting in dangerous areas and signal stations were also provided.

During 80-90s, existing wharfs were reconstructed and new boat yards were established on major Ukrainian rivers. In 1884-1886, the so-called "cossack run" was cleared on Staro-Kaidatsky rapid. In the same years, Sulkovsky, the engineer, developed a project for complete cleaning of the rapid area, but it wasn't implemented. Just wooden walls were constructed along old channels. In 1893, Leliavsky, the engineer, proposed a project for channel locking, and in 1897, a dedicated committee developed a new project of locking. But all the projects remained on paper. Technological progress was the main obstacle for this, especially in railway transport which effectively competed with river transport.

By the end of the $19^{\text {th }}$ century, the wharfs which had exits to the railways vigorously developed: Smolensk, Orsha, Mogyleov, Zjlobyn, Rechytsa, Cherkasy, Kremenchuk, Katerynoslav, Oleskandrivsk (Kichkas ferry) [Дудка, Дудка, 2010: 55]. Generally, before 1875, workers of Dnipro river transport complained on minor quantity of convenient wharfs, near-bank area contaminated by accidental building sites, lack in convenient places for ship (steamboats) holding and wintering. Due to the efforts of the regional shipping transport office, over 70 wharfs were commissioned by the end of the century. Some of them got their own profiles: bread, timber, coal, etc.

Twentieth Century: New Trends. Industrial development in the beginning of the new century set new conditions for river transport. Establishment of iron and steel works and machine-building companies in Katerynoslav, Kyiv, Kharkiv and Donbas as well as development of railway communication facilitated the increase of cargo turnover. Respectively, the number of steam ships on the Dnipro in 1906 increased up to 440 units; the number of non-selfpropelled ships, barges, in particular, was up to 2.5 thousands. In the beginning of the $20^{\text {th }}$ century, Dnipro steam shipping companies owned $1 / 5$ of the total amount of steam ships in the Russian Empire. Only companies of Volga basin owned more (2,099 steam ships).

Kyiv, Cherkasy, Kremenchuk, Katerynoslav, Oleksandrivsk and Kherson became the largest ports on the Dnipro. Up to 900 ships were annually serviced in Cherkasy port. Cost of loaded cargo was $2 \mathrm{mln}$ rubles and unloaded cargo cost $3 \mathrm{mln}$ rubles. In particular, in 1905, 687 ships arrived with a cargo which weight was 5451800 poods and cost - 2465679 rubles. In 1907-1909, Kyiv port received over 70 steam ships each month. Within this time, Kyiv port handled approximately $19 \mathrm{mln}$ poods of various cargoes and $2.5 \mathrm{mln}$ poods were shipped.

Inspector of Katerynoslav shipping office of Kyiv district recorded that till January 1911, 87969324 poods which cost 65259920 rubles were shipped by the Dnipro [Константінова, 2010].

At the same time, natural and social conditions hindered the utmost usage of Dnipro basin water ways.

The first ones lasted since the previous century and required intervention and sufficient investments. As per testimonials of academician V. I. Vernadsky, in 1909, a cross-agency committee was established to develop a work schedule to improve and develop water ways of the Empire. Engineer V. Y. Timonov was the head of the Committee. Under his supervision, "General Schedule" of capital works on major rivers in 1912-1916 was completed. This schedule provided deepening of the Dnipro fairway from Kherson to Oleksandrivsk and from Katerynoslav to the Berezyna river mouth, locking of Dnipro rapids and usage of water cascade power for industrial purposes as well as construction of up to 57 miles long channel. Once implemented, the schedule could actually revive the trade route from the Varangians to the Greeks and could connect ports of the Baltic and Black Seas through the river systems. Another projects were also developed [Графpmuo, 1905]. But the First World War and resulting social collapses postponed these plans.

As for the social conditions, they arose from modernization processes within the old political and social structures, under conditions of police and authoritarian rule when monarchy tried to control the economy development as well as noncompleted and inconsistent reforms. 
Among critical issues arising from the shipping development on the Dnipro, one should mention minor governmental support in comparison to that provided to the railways, contradictory measures to protect minor coastal shipping and no restrictions in relation of large coastal shipping. Unreasonable customs police sufficiently influenced the economic conditions of river ports.

After 1917, navigation on the Dnipro almost stopped because of the civil war in Ukraine. The river facilities fell into decay, ships and wharfs were destroyed and fairways got contaminated.

When in the mid twenties, a changeover to NEP started and a related economy growth was observed, it was found that only 76 steam ships and 131 ships without steam engines applicable for usage remained. That meant that everything had to be started from nothing. In 1924, only 300 thou. tons of cargo were carried.

The improvements were very slowly. Within four years, cargo turnover was 752 thou. tons; in $1930-5.5 \mathrm{mln}$ tons. After 1929, which in the Soviet historiography was called "the year of great breakthrough", forced industrialization started. Dniprobud became one of its symbols. An artificial storage basin appeared because of the hydro-electric power plant and the dam which flooded the rapid area of the Dnipro bed. The Dniprelstan locking facility made it possible to easily ship along the whole Dnipro bed.

Comparing non-implemented projects of a single water way creation of the $19^{\text {th }}$ century with actual hydraulic structures of the $20^{\text {th }}$ century, modern authors emphasize on a significant difference in engineering approaches to resolution of the "Great Dnipro" issue. While prerevolutionary development focused on the system of local locks and by-pass channels with small auxiliary hydroelectric power plants, the implemented Soviet project of hydroelectric power plant cascade was mainly intended to energize iron and steel making works and aluminumproducing facility in Zaporizhzhia. Formation of fullyfeatured river way was viewed as an issue of secondary importance with negative consequences: destruction of fertile lands of the Great Meadow, displacement of people from the villages of flooded areas, contamination and standstill of Dnipro water, environmental problems of nearbank areas, a constant risk of regional man-induced disaster. But all these issues were revealed during the period outside the time frame of our investigation.

\section{Conclusions}

When generally estimating the shipping on the Dnipro within 1875-1932, one should mention that it was the period of gradual substitution of river passenger transportation and cargo handling by traditional ships for steam ships and towed barges. If in 1895 , there were 186 steam ships in the Dnipro basin, in 1900, their number increased to 356 ships. Only in 1895-1897, ship owners purchased 241 steam ships.

Modernization of ships including changeover to steam haulage required major capitals. Thus, private owners lost the competition to stock companies and other communities of ship holders. As per statistics of 1890 , stock companies owned 185 ships, including 89 steam ships (48\%). These were the ships of the best size, most powerful engines and the best price. The second large ship owners were non-stock and trade companies. They owned 508 ships, including 51 steam ships (10\%). Governmental and community-based companies owned 22 steam ships. Finally, there were private owners (nobles, merchants, commo- ners, foreign residents) who possessed over 1,300 ships, including 72 steam ships (5.5\%) [Кривко, 2006: 76]. Therefore, major stock companies had the best competitive positions.

Some phenomena typical to the Dnipro shipping during the major part of the $19^{\text {th }}$ century gradually disappeared due to the introduction of innovative trends in river transport and development of railway network. We are talking about ships constructed for a single navigation (bilyans, bryankas, galleys, liuzes) as well as rafts and pilot guidance through the rapids.

Conversion to engine-driven ships caused decrease in price of river transportation and thus increase in cargo turnover. In the beginning of period under analysis (before 1875), it reached, on average, $16.8 \mathrm{mln}$ poods a year. Ten years later it was $23.6 \mathrm{mln}$ poods. In 1895, cargoes transported by the rivers of the Dnipro basin increased to 222 mln poods; in 1902 - to 238 mln poods [Кривко, 2006: 77].

Development of navigation on the Dnipro preconditioned the activity of regional shipping transport office in Kyiv which did much for river bed cleaning and establishment of wharfs, ship winter stands, facilities for ship building and repair. At the same time, the area of Dnipro rapids which divided the river in two unequal parts sufficiently hindered the development of water transport within the specified period, which relative share in the whole Russian Empire was insufficient.

\section{REFERENCES}

1. Afanasyev-Chuzhbinsky, A., 1861. A trip to southern Russia. Essays of the Dnieper. Part 1., St.Petersburg: Tipografiya Morskogo ministerstva, 466 p. (rus).

2. Belyavsky, P.E., 1991. Dnieper. Encyclopedic dictionary of F.A. Brockhaus, I.A. Efron. Vol. 20. Yaroslavl: Terra Publishing, 791-808 (rus).

3. Graftio, G.O., 1905. Report on the trip to the Dnieper rapids. Materials for the description of Russian rivers and the history of the improvement of their navigable conditions. Issue. 9, St.Petersburg: Tipografiya Morskogo ministerstva, 16 p. (rus).

4. Gurzhii, I.O., 1968. Ukraine in the system of the all-Russian market of the $60-90$ s of the nineteenth century. Kyiv: Naukova dumka, 191 p. (ukr)

5. Dudka, V.I. and Dudka, L.G., 2010. Dnieper transport artery in the $19^{\text {th }}$ century. The Great Patriotic War in the History of the Ukrainian People: A Collection of Materials for a Regional Scientific and Practical Conference. Shcherbatykh Publisher, Kremenchuk: 47-57 (ukr).

6. Zavalniuk, K.V., 1998. Trade in industrial goods between Ukraine and Belarus in the second half of the nineteenth century. Ukrayinskyy istorychnyy zhurnal. Issue 4: 43-55 (ukr).

7. Konstantinova, V.M., 2010. Development of communication and transport as a component of urbanization processes in the south of Ukraine in the second half of the nineteenth and early twentieth centuries. Literatura i kultura Polissya. Coll. sciences works. Issue 61. Nizhyn: P. 70-74 (ukr).

8. Krivko, I.M., 2006. Development of river transport in southern Ukraine in the second half of the nineteenth century. Scientific works of the historical faculty of Zaporizhzhya State University. Issue XX. Zaporizhzhia: 74-79 (ukr).

9. Materials related to the device of the Alexander Harbor. State Archives of the Zaporizhzhia Region. Fond 1. Opys 1. Sprava 825.

10. Review of the economic statistics of Russia, 1849. St.Petersburg: Tipografiya Imperatorskoy akademii, 252-254 (rus).

11. Chernikov, I.I., 2003. Fleet on the rivers. Publishing house «Polygon», St.Petersburg, 704 p. (rus). 
Додонов Роман,

доктор філософських наук, професор,

Київський університет імені Бориса Грінченка

\section{СПЕЦИФІКА СУДНОПЛАВСТВА В БАСЕЙНІ ДНІПРА В 1875-1932 pp.}

У статті проаналізовано динаміку водного транспорту в Дніпровському басейні в останню чверть XIX першу третину XX століття. Зазначений хронологічний період характеризується співіснуванням традиційних засобів пересування водними шляхами із модерними нововведеннями. Технологічні новації у вигляді парового двигуна, залізного корпусу, гребного гвинта, а незабаром і двигуна внутрішнього згоряння спричинили справжню революцію на річковому транспорті. Показано, як під впливом вказаних новацій змінюється структура парку суден, збільшується їх загальний тоннаж, швидкість перевезень, зменшується собівартість послуг. Дніпро починає працювати на потреби промисловості, що бурхливо розвивається на його берегах. Загальна меридіональна орієнтація р. Дніпро з притоками, з'єднуючи собою лісову, лісо-степну та степну природнокліматичні зони, обумовила зміст вантажопотоків: з півночі постачали ліс та продукти лісообробної промисловості, 3 півдня - хліб, сіль, вугілля.

Автор описує також еволюцію річкового флоту, у тому числі - пароплавів. За переписом 1890 року, на ріках України налічувалося 220 пароплавів, у 1906 році їх кількість лише на Дніпрі збільшилася до 440 одиниць, тоді як кількість несамохідних барж досягала 2,5 тис. Згадуються найбільші об'єднання власників пароплавів: "Російське товариство пароплавства і торгівлі" (РОПіТ), "Товариство пароплавства по Дніпру", "Друге товариство пароплавства по Дніпру". Вони експлуатували понад 70 пристаней на Дніпрі.

Водночас, географічні умови, включаючи наявність порогів, ділянок 3 недостатньою глибиною, примхи погоди тощо значно ускладнювали навігаційні умови Дніпра. На відміну від басейнів Волги, Дону, річок Сибіру та Далекого Сходу, Дніпровські пороги ізолювали Верхню та Середню Наддніпрянщину від Низу, що отримало назву проблеми "Великого Дніпра", яка була вирішена у 1932 році через будівництво греблі Дніпровської ГЕС.

Ключові слова: Дніпро; Дніпровський басейн; річковий транспорт; пароплави; пороги; Дніпробуд.

\section{ЛГТЕРАТУРА}

1. Афанасьев-Чужбинский А. Поездка в Южную Россию. Очерки Днепра. СПб.: Типография Морского министерства, 1861. 4.1. $466 \mathrm{c}$.

2. Белявский П.Е. Днепр. Энциклопедический словарь Ф.А. Брокгауз, И.А. Ефрон. Ярославль: Терра, 1991. Т. 20. С. 791-808.

3. Графтио Г. О. Отчет о командировке на Днепровские пороги. Материалы для описания русских рек и истории улучшения их судоходных условий. Вып. 9. СПб.: Тип. министерства путей сообщения (Т-ва И.Н. Кушнерев и Ко), 1905. 16 с.

4. Гуржій І.О. Україна в системі всеросійського ринку 60-90-х років XIX ст. К.: Наукова думка, 1968. 191 с.

5. Дудка В.І., Дудка Л.Г. Дніпровська транспортна артерія у XIX столітті. Велика Вітчизняна війна в історії українського народу: Збірник матеріалів регіональної науково-практичної конференції. Кременчук: ПП Щербатих, 2010. С. 47-57.

6. Завальнюк К.В. Торгівля промисловими товарами між Україною та Білорусією у другий половині XIX ст. Український історичний журнал. 1998. Вип. 4. С. 43-55.

7. Константінова В.М. Розвиток шляхів сполучення і транспорту як складова урбанізаційних процесів на півдні України другої половини XIX - початку XX ст. Література і культура Полісся. Зб. наук. праць. Вип. 61. Ніжин, 2010. С. 70-74.

8. Кривко І.М. Розвиток річкового транспорту на півдні України у другій половині XIX ст. Наукові праці історичного факультету Запорізького державного університету. Запоріжжя: ЗНУ, 2006. Вип. XX. С. 74-79.

9. Материалы, относящиеся к устройству Александровской гавани. Державний архів Запорізької області. Ф. 1. Оп. 1. Спр. 825.

10. Обозрение экономической статистики России. СПб.: Типография Императорской академии, 1849. С. $252-254$.

11. Черников И.И. Флот на реках. СПб.: ООО Изд-во «Полигон», 2003. 704 с.

(C) Додонов Роман

Надійшла до редакції 14.08.2018 